\title{
PENGEMBANGAN MEDIA PEMBELAJARAN AUDIO VISUAL PADA MATA PELAJARAN SEJARAH KEBUDAYAAN ISLAM (SKI)
}

\author{
Dedi Setyawan $^{1}$ dan Andini Dwi Arumsari ${ }^{2}$ \\ ${ }^{1}$ Universitas Dr. Soetomo Surabaya \\ ${ }^{2}$ Universitas Narotama Surabaya \\ andini.dwi@narotama.ac.id
}

\begin{abstract}
Abstrak
Media pembelajaran audio visual pada proses belajar mengajar digunakan oleh para pendidik untuk memaksimalkan penyampaian materi pelajaran yang diberikan untuk siswa. Setiap pendidik mengembangkan media pembelajaran tersebut, sesuai dengan mata pelajaran yang diberikan. Misalnya penggunaan media pembelajaran audio visual slide show dan film pada mata pelajaran Sejarah Kebudayaan Islam. Tujuan dari penelitian ini adalah mengetahui bagaimana pengembangan media pembelajaran audio visual slide show dan film pada mata pelajaran Sejarah Kebudayaan Islam (SKI). Penelitian ini menggunakan eksperimen yang dilakukan dengan pretes dan post test. Desain penelitian yang digunakan adalah untreated control group desain with dependent pretest and post test samples. Hasil dari penelitian ini adalah pengembangan media pembelajaran audio visual yang digunakan adalah dengan menggunakan media pembelajaran audio visual slide show dan film, dan ada pengaruh media pembelajaran audio visual slide show dengan taraf signifikansi ( $p$ ) 0,000 ( $p<0,01)$ dan film dengan taraf signifikansi ( $p$ ) 0,000 ( $p<0,01)$ yang signifikan pada pemahaman peserta didik dalam mata pelajaran sejarah kebudayaan islam (SKI).
\end{abstract}

\section{PENDAHULUAN}

Proses balajar mengajar yang dilakukan guru tidak lepas dari penggunaan media pembelajaran pada mata pelajaran yang sedang diajarkan, karena media dalam pembelajaran mempunyai peran perlu di perhatikan untuk memaksimalkan kegiatan proses pembelajaran. Secara epistimologi, media diartikan sebagai segala sesuatu yang digunakan untuk mengirimkan pesan (message), merangsang pikiran, perasaan, perhatian dan kemauan peserta didik sehingga mampu mendukung proses belajar (Ali, 2007). Penggunaan media merupakan mampu 
menyampaikan pesan dari orang yang memberi pesan kepada orang yang menerima pesan baik berupa perangkat keras ataupun perangkat lunak. Selanjutnya, Suryani dan Agung (2012) mengatakan bahwa arti dari media pembelajaran adalah bahan, alat, atau teknik yang dipakai dalam proses pembelajaran. Media pembelajaran digunakan dengan tujuan supaya proses pemberian informasi yang diberikan oleh guru kepada siswa dapat berlangsung secara tepat guna dan berdaya guna. Media pembelajaran menjadi salah satu hal sangat dibutuhkan dalam proses belajar mengajar. Hal tersebut disebabkan oleh penggunaan media bukan hanya sebagai alat bantu mengajar, namun lebih menjadi bagian yang tak terpisahkan dalam proses pembelajaran.

Materi pelajaran yang dirasa sulit dimengerti oleh siswa bisa disederhanakan menggunakan bantuan media (Djamarah \& Zain, 2006). Namun, banyak guru yang belum memaksimalkan penggunaan media dalam proses pembelajaran yang dilakukan. Guru masih banyak menggunakan metode pembelajaran secara konvensional, yaitu dengan metode ceramah dan pemberian tugas. Kelemahan dari metode ceramah adalah (1) para pendidik lebih aktif untuk menerangkan materi pelajaran oleh karena itu membuat peserta didik menjadi pasif karena perhatian hanya terpusat pada pendidik, (2) peserta didik diharuskan mengikuti apapun yang disampaikan oleh pendidik walaupun pada kenyataannya peserta didik ada yang bersifat kritis namun hal tersebut tidak akan merubah apa yang disampaikan pendidik karena pendidik dianggap selalu benar, dan (3) peserta didik menjadi lebih cepat bosan dan merasa mengantuk, karena dalam metode ini, hanya pendidik yang aktif dalam proses belajar mengajar, sedangkan para peserta didik hanya duduk diam mendengarkan penjalasan yang telah diberikan oleh pendidik.

Salah satu contoh mata pelajaran yang selama ini diberikan dengan metode ceramah dan pemberian tugas adalah mata pelajaran Sejarah Kebudayaan Islam (SKI). Menurut data empiris yang didapatkan selama ini, peserta didik kurang memberikan minat dan perhatian seksama pada mata pelajaran sejarah tersebut, sehingga hasil evaluasi yang didapat sering juga kurang memuaskan. Seperti yang diungkapkan Hasan (2012) pelajaran sejarah dianggap tidak menarik dan membosankan, dan akhirnya dianggap tidak penting oleh peserta didik. Hasil wawancara yang telah dilakukan kepada guru mata pelajaran Sejarah Kebudayaan Islam (SKI) di SD Yapita Surabaya, mengatakan bahwa metode pembelajaran yang digunakan dalam mata pelajaran Sejarah Kebudayaan Islam (SKI) di SD Yapita adalah dengan metode ceramah. Dengan menggunakan metode ceramah tersebut, siswa kelas V di SD Yapita kurang tertarik 
dengan materi pelajaran yang diberikan. Maka dari itu para pendidik harus memahami mata pelajaran yang akan diajarkan ke peserta didik, serta menggunakan metode dan media pembelajaran yang sesuai dengan mata pelajaran yang diajarkannya.

Pada siswa yang berada di SD Islam, pelajaran yang sulit untuk mereka pahami adalah pelajaran Sejarah Kebudayaan Islam (SKI). Peran dan fungsi pelajaran sejarah kebudayaan Islam (SKI) sangat penting bagi individu, agama dan implementasinya terhadap bangsa dan Negara. Mata pelajaran tersebut juga mempelajari tentang unsur-unsur hikmah dibalik seorang tokoh Nabi Muhammad SAW dalam memimpin seluruh umat Islam maupun non Islam. Sejarah Kebudayaan Islam mengajarkan tentang asal usul, perkembangan, peranan kebudayaan atau peradaban Islam dan para tokoh yang berprestasi dalam sejarah Islam di masa lampau, mulai dari perkembangan masyarakat Islam pada masa nabi Muhammad SAW, khulafaur Rasyidin, bani Umayyah, bani Abbasiyah, Ayyubiyah, sampai perkembangan Islam di Indonesia. Mata pelajaran Sejarah Kebudayaan Islam (SKI) merupakan perkembangan perjalanan hidup manusia muslim dari masa ke masa dalam usaha bersyarie ${ }^{\text {ee }}$ dan berakhlak serta dalam mengembangkan system kehidupan yang dilandasi oleh akidah (Muhaimin, 2005, dalam Sofi, 2016).

Penggunaan media pembelajaran dalam proses belajar mengajar, salah satunya adalah dengan cara menggunakan media pembelajaran audio visual. Media audio visual yaitu media yang dapat dilihat sekaligus di dengar seperti film suara, video, televise dan sound slide. Media audio visual adalah media penyampai informasi yang memiliki karakteristik audia (suara) dan visual (gambar). Media audio-visual adalah media yang merupakan gabungan antara audio dan visual yang dibuat sendiri seperti gambar yang digabungkan dengan suara (Wingkel 2009, dalam Purwono dkk, 2014).

Dalam penggunaanya, media pembelajaran audio visual dapat dikembangkan menjadi media pembelajaran audio visual dengan menggunakan slide show dan media pembelajaran audio visual dengan menggunakan film. Audio visual slide show ini mamakai softwere microsoft power point dalam bentuk slide presentasi ditambahkan dengan gambar yang menarik. Media power point adalah sebuah program aplikasi yang digunakan untuk melakukan presentasi, dan merupakan salah satu program aplikasi yang ada di microsoft office. Program ini sudah terinstal di perangkat lunak masing-masing guru, sehingga akan mengurangi beban dan hambatan guru dalam pengembangan proses belajar mengajar. Guru bisa membuat suatu pembelajaran yang lebih menarik dari pada sekedar ceramah. Program PowerPoint ini memiliki 
fiture-fiture yang sederhana dan mudah dalam penggunaanya. Keuntungan lain dari software ini selain dapat memasukkan teks dan gambar, kita juga bisa memasukkan file suara dan file video untuk mendukung dalam proses presentasi.

Selain media pembelajaran slide show, dalam proses pembelajaran untuk mata pelajaran sejarah kebudayaan islam (SKI) juga bisa menggunakan film. Media film adalah salah satu media menggunakan unsur suara dan juga unsur gambar yang bisa dilihat. Sistem multimedia ini serba guna, mudah dalam penggunaanya, dan efektif untuk pembelajaran perorangan maupun. Jadi, tujuan penelitian ini adalah untuk mengetahui bagaimana pengembangan media pembelajaran audio visual slide show dan film pada mata pelajaran Sejarah Kebudayaan Islam (SKI). Pengembangan media pembelajaran audio visual slide show dan film dapat dilihat dari pemahaman siswa terhadap mata pelajaran Sejarah Kebudayaan Islam (SKI).

\section{METODE PENELITIAN}

Penelitian ini menggunakan eksperimen yang dilakukan dengan pretes dan post test. Desain penelitian yang digunakan adalah untreated control group desain with dependent pretest and post test samples (Shadish, Cook, dan Campbell, 2002). Partisipan dalam penelitian ini dibagi menjadi kelompok kontrol dan kelompok eksperimen. Kelompok eksperimen diberikan manipulasi berupa pembelajaran dengan menggunakan media audio visual slide show dan film. Sedangkan kelompok kontrol tidak diberikan pembelajaran dengan menggunakan media audio visual (pembelajaran konvensional).

Penelitian ini dilakukan di SD Yapita Surabaya pada siswa kelas V. Mata pelajaran Sejarah Kebudayaan Islam (SKI) diberikan sebanyak seminggu sekali pada kelas tersebut. Setiap pertemuan, berlangsung selama 60 menit. Subyek dalam penelitian ini berjumlah 97 siswa. Instrumen penelitian yang digunakan berupa pre test dan post test tentang pemahaman siswa dalam mata pelajaran Sejarah Kebudayaan Islam (SKI). Dalam tes ini, subyek diminya untuk menjawab pertanyaan yang diberikan. Jika subyek memberikan jawaban dengan benar akan mendapatkan nilai 1 dan jika memberikan jawaban yang salah akan dinilai 0. Pre test dan post test yang diberikan ke siswa, berisikan 30 pertanyaan yang terkait dengan pokok bahasan yang ada di mata pelajaran Sejarah Kebudayaan Islam (SKI).

\section{HASIL}


Sebelum melakukan perhitungan hasil tes siswa, dilakukan uji validitas instrument penelitian yang digunakan. Instrumen yang valid berarti alat ukur yang digunakan untuk mendapatkan data (mengukur) itu valid (Sugiyono, 2008). Valid berarti instrument tersebutdapat digunakan untuk mengukur apa yang seharusnya diukur. Pengujian validitas instrument, salah satunya adalah dengan pengujian validitas konstruksi (Construct Validity). Untuk menguji validitas konstruksi, dapat digunakan pendapat para ahli (judgment experts). Dalam hal ini setelah instrument dikonstruksikan tentang aspek-aspek yang akan diukur dengan berlandaskan teori tertentu, maka selanjutnya dikonsultasikan dengan para ahli. Validasi oleh ahli dilakukan untuk mendapatkan rumusan isi, teoritis efisiensi, kemungkinan implementasi, dan kemenarikan model yang memliki aras kelayakan yang sesuai. Validasi isi dilakukan oleh ahli pendidikan yang berpendidikan master, dan mengabdi diri di bidang pendidikan di lembaga perguruan tinggi.

Uji prasyarat analisis dalam penelitian ini dilakukan sebelum dilakukan uji beda. Uji prasyarat yang dilakukan berupa uji normalitas. Berikut ini adalah hasil uji normalitas tersebut:

Tabel 1 Hasil Uji Normalitas

\begin{tabular}{lcc}
\hline \multicolumn{1}{c}{ Data } & Signifikansi & Normalitas \\
\hline Kelompok kontrol & 0,156 & Normal \\
\hline Kelompok eksperimen film & 0,299 & Normal \\
\hline Kelompok eksperimen slide show & 0,060 & Normal \\
\hline
\end{tabular}

Selanjutnya, dilakukan uji homogenitas. Uji homogenitas ini dilakukan dengan tujuan untuk mengetahui apakah varian populasi sama atau tidak. Berikut ini adalah hasil uji homogenitas tersebut:

Tabel 2 Hasil Uji Homogenitas

\begin{tabular}{lcc}
\hline \multicolumn{1}{c}{ Data } & Signifikansi & Homogenitas \\
\hline Media audio visual film & 0.055 & Homogen \\
\hline Media audio visual slide show & 0.171 & Homogen \\
\hline
\end{tabular}

Setelah diperoleh hasil uji normalitas dan uji homogenitas, selanjutnya dapat diperoleh hasil selisih dan pengujian data untuk menganalisis hasil skor tes pemahaman siswa yang dilakukan dengan T-Test. Berikut hasil t-test yang telah dilakukan:

Tabel 3 Hasil Uji t kelompok kontrol dan eksperimen slide show Independent Samples Test

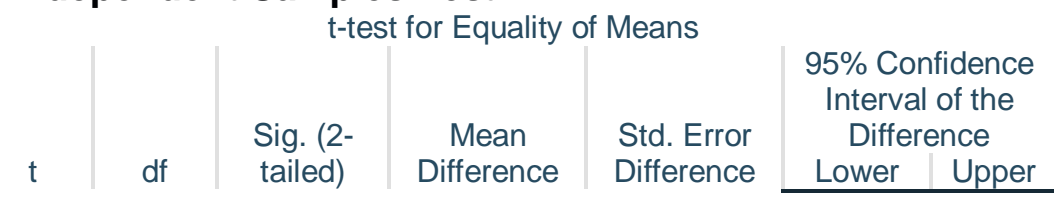




\begin{tabular}{l|l|r|r|r|r|r|r|r|r|}
\hline selisih & Equal variances assumed & $-5,234$ & 58 &, 000 & $-3,434$ &, 656 & $-4,748$ & $-2,121$ \\
\cline { 2 - 9 } & $\begin{array}{l}\text { Equal variances not } \\
\text { assumed }\end{array}$ & $-5,893$ & 48,763 &, 000 & $-3,434$ &, 583 & $-4,606$ & $-2,263$ \\
\hline
\end{tabular}

Dari tabel 3, dapat diartikan bahwa signifikansi yang didapat dari perhitungan yang telah dilakukan sebesar 0,00. Artinya, ada pengaruh metode pembelajaran slide show yang signifikan terhadap pemahaman siswa pada pelajaran Sejarah Kebudayaan Islam (SKI).

\section{Tabel 4 Hasil Uji T kelompok kontrol dan eksperimen film Independent Samples Test}

\begin{tabular}{|c|c|c|c|c|c|c|c|c|}
\hline & \multicolumn{7}{|c|}{ t-test for Equality of Means } \\
\hline & & \multirow[b]{2}{*}{$\mathrm{t}$} & \multirow[b]{2}{*}{$d f$} & \multirow{2}{*}{$\begin{array}{l}\text { Sig. (2- } \\
\text { tailed) }\end{array}$} & \multirow{2}{*}{$\begin{array}{l}\text { Mean } \\
\text { Difference }\end{array}$} & \multirow{2}{*}{$\begin{array}{l}\text { Std. Error } \\
\text { Difference }\end{array}$} & \multicolumn{2}{|c|}{$\begin{array}{l}95 \% \text { Confidence } \\
\text { Interval of the } \\
\text { Difference }\end{array}$} \\
\hline & & & & & & & Lower & Upper \\
\hline selis & $\begin{array}{l}\text { Equal variances } \\
\text { assumed }\end{array}$ & $-5,029$ & 58 &, 000 & $-4,149$ &, 825 & $-5,800$ & $-2,497$ \\
\hline & $\begin{array}{l}\text { Equal variances not } \\
\text { assumed }\end{array}$ & $-5,768$ & 43,615 & ,000 & $-4,149$ & ,719 & $-5,598$ & $-2,699$ \\
\hline
\end{tabular}

Dari tabel 4, dapat diartikan bahwa signifikansinya sebesar 0,00. Artinya, ada ada pengaruh metode pembelajaran slide show film yang signifikan terhadap pemahaman siswa pada pelajaran sejarah kebudayaan islam (SKI).

\section{PEMBAHASAN}

Proses belajar mengajar yang diberikan kepada siswa, biasanya hanya sebatas dengan pemberian materi pelajaran melalui buku pelajaran yang telah disediakan oleh pihak sekolah. Untuk itu, perlu ada pengembangan media pembelajaran yang digunakan oleh guru dalam proses belajar mengajarnya, terutama di materi pelajaran Sejarah Kebudayaan Islam (SKI). Awalnya, guru memberikan materi Sejarah Kebudayaan Islam (SKI) melalui metode konvensional, yaitu melalui ceramah dan latihan soal saja. Namun, karena terus berkembangnya media pembelajaran, perlu dilakukan evaluasi terhadap metode pembelajaran yang digunakan oleh guru dalam proses belajar mengajar.

Pengembangan media pembelajaran melalui audio visual sangat dibutuhkan dalam mata pelajaran Sejarah Kebudayaan Islam (SKI) tersebut, terutama bagi guru dan siswa. Dalam media pembelajaran, materi tersebut dibuat dengan menarik, dan ditambahkan gambar-gambar yang terkait dengan materi yang diajarkan oleh guru. Musfiqon (2012) berpendapat bahwa pembelajaran yang memakai multimedia menunjukkan hasil yang lebih efektif dan efisien serta bisa meningkatkan hasil belajar siswa. Media audio visual itu sendiri termasuk ke dalam jenis multimedia, yaitu salah satu macam media yang selain mempunyai unsur suara juga 
mempunyai unsur gambar yang dapat dilihat, seperti misalnya rekaman video, berbagai ukuran film, slide show dan lain sebagainya. Pemakaian media audio visual mampu meningkatkan perhatian siswa dengan menggunakan tampilan yang lebih menarik. Siswa juga akan merasa tidak mau ketinggalan dengan jalan cerita pada video tersebut jika mereka teralihkan konsentrasi dan perhatiannya. Hal tersebut dikarenakan media audio visual menampilkan gambar dan informasi nyata pada saat proses belajar mengajar, sehingga meningkatkan adanya aktivitas diri siswa (Fujiayanto, Jayadinata, \& Kurnia, 2016).

Guru berperan dan berpengaruh besar dalam proses belajar mengajar. Hal tersebut dikarenakan guru yang bertugas untuk memilih, merencanakan, mempersiapkan dan mengembangkan sebuah materi pembelajaran yang kemudian materi tersebut akan disampaikan ke siswa. Awalnya, guru memberikan pembelajaran sejarah kebudayaan islam dengan menggunakan metode pembelajaran yang konvesnsional, yaitu dengan menggunakan metode ceramah dan pemberian tugas. Hal ini membuat siswa merasa bosan dan tidak menyenangkan. Dalam proses belajar tersebut, siswa hanya melakukan aktivitas menghafal saja, tanpa benar-benar memahami materi dari mata pelajaran sejarah kebudayaan islam. Padahal, dalam mata pelajaran sejarah kebudayaan islam ini membahas sejarah-sejarah islam di masa lampau. Beberapa guru masih beranggapan bahwa pendidikan lebih mempunyai arti sebagai proses transfer ilmu dari guru ke siswa tanpa memperhatikan bagaimana siswa dapat memahami materi yang disampaikan (Naim, 2016).

Semakin berkembangnya jaman di bidang teknologi dan informasi, guru dituntut untuk lebih kreatif dalam memberikan materi pembelajaran dengan menggunakan metode dan media pembelajaran yang mampu memberikan pemahaman kepada siswa terkait materi yang disampaikan tersebut. Media yang digunakan guru bisa berupa media audio visual slide show dan film. Pemberian materi dengan menggunakan media pembelajaran audio visual ini disesuaikan dengan materi pembelajaran yang akan diberikan ke siswa.

Dalam penelitian ini, peneliti meminta guru untuk memberikan materi pembelajaran Sejarah Kebudayaan Islam (SKI) dengan menggunakan media pembelajaran audio visual slide show dan film. Penggunaan media pembelajaran tersebut memberikan pengaruh yang signifikan terhadap pemahaman siswa pada mata pelajaran Sejarah Kebudayaan Islam (SKI). Adanya pengaruh media pembelajaran audio visual slide show dan film ini ditunjukkan dengan nilai signifikansi yang ada di tabel 3 dan tabel 4. Pada tabel 3, nilai signifikansi untuk pengaruh media pembelajaran slide show sebesar 0,00. Artinya ada pengaruh media 
pembelajaran audio visual slide show yang signifikan terhadap pemahaman siswa pada mata pelajaran Sejarah Kebudayaan Islam (SKI). Pada tabel 4, nilai nilai signifikansi untuk pengaruh media pembelajaran film sebesar 0,00. Artinya ada pengaruh media pembelajaran audio film yang signifikan terhadap pemahaman siswa pada mata pelajaran Sejarah Kebudayaan Islam (SKI).

Dengan menggunakan media pembelajaran audio visual slide show, guru dapat dengan mudah menyampaikan informasi dan memberikan gambaran yang lebih konkret kepada siswa. Kemudahan yang dialami guru tersebut mulai dari kemudahan untuk mendapatkan media audio visual slide show tersebut, mudah untuk membuat materinya, dan mudah untuk menggunakannya (Ananda \& Sudarso, 2018).

Media pembelajaran audio visual lain yang digunakan adalah media pembelajaran audio visual film. Dengan menggunakan media pembelajaran audio visual film, materi pembelajaran di berikan dengan menggunakan cerita bergerak dan bersuara melalui film. Dalam media pembelajaran ini, materi pembelajaran Sejarah Kebudayaan Islam (SKI) diberikan dengan memasukkan beberapa tulisan singkat dan gambar-gambar yang menarik ke dalam film. Media pembelajaran audio visual film juga mampu membangun imajinasi yang sesuai dengan materi pelajaran dari film yang disaksikan oleh siswa (Husmiati, 2010).

Dari hasil yang didapat, ada perbedaan pengaruh media pembelajaran audio visual slide show dan film pada pemahaman peserta didik dalam mata pelajaran sejarah kebudayaan islam (SKI). Media pembelajaran audio visual film lebih memberikan pengaruh pada pemahaman peserta didik dalam mata pelajaran sejarah kebudayaan islam (SKI) dibandingkan dengan media pembelajaran audio visual slide show. Pengalaman belajar siswa salah satunya juga dapat diperoleh melalui film. Hal ini ditunjukkan dengan hasil observasi di lapangan ketika pemberian materi Sejarah Kebudayaan Islam (SKI) pada siswa kelas V di SD Yapita Surabaya. Siswa lebih fokus pada materi pelajaran yang diberikan oleh gurunya dengan menggunakan media pembelajaran slide show. Banyak pertanyaan yang diberikan oleh siswa-siswa tersebut terkait dengan materi pelajaran yang diberikan. Dengan menggunakan media pembelajaran slide show dalam pembelajaran merupakan salah satu hal yang memberikan peningkatan yang signifikan pada pemahaman siswa pada mata pelajaran Sejarah Kebudayaan Islam (SKI) siswa pada kelompok eksperimen. Hal tersebut disebabkan karena pada waktu pemberian materi Sejarah Kebudayaan Islam (SKI), siswa menjadi lebih memperhatikan, memahami, dan menganalisa certia yang dilihat dan di dengarnya dalam film tersebut. 
Selain itu, dengan menggunakan slide show, dapat memberikan pengalaman belajar yang tidak didapatkan siswa di dalam kelas karena keterbatasan ruang dan waktu yang mereka miliki. Hal ini juga dapat mengasah kemampuan analitis siswa terhadap slide show yang ditampilkan berdasarkan teori dan konsep yang telah mereka pelajari sebelumnya.

\section{KESIMPULAN}

Berdasarkan penelitian yang telah dilakukan yaitu pengembangan media pembelajaran audio visual pada mata pelajaran Sejarah Kebudayaan Islam (SKI), dapat disimpulkan bahwa: (1) Pengembangan media pembelajaran audio visual yang digunakan adalah dengan menggunakan media pembelajaran audio visual slide show dan film, dan (2) Ada pengaruh media pembelajaran audio visual slide show dan film yang signifikan pada pemahaman peserta didik dalam mata pelajaran sejarah kebudayaan islam (SKI).

\section{REFERENSI}

Ali, Muhammad. (2007). Guru dalam Proses Belajar Mengajar. Bandung: Sinar Baru Algensindo.

Ananda, D. A., dan Sudarso. (2018). Pengaruh Media Audio Visual dan Power Point terhadap Hasil Belajar Dribbling Sepak Bola pada Siswa Kelas X Multimedia 3 dan X SMK Yapalis Krian. Jurnal JPOK, Vol 06 nomer 02.

Djamarah, Syaiful Bahri., dan Zain, Aswan. (2006). Strategi Belajar Mengajar. Jakarta: Penerbit Rinek Cipta

Fujiyanto, A., Jayadinata, A. K., Kurnia, D. (2016). Penggunaan Media Audio Visual untuk Meningkatkan Hasil Belajar Siswa pada Materi Hubungan Antar Makhluk Hidup. Jurnal Pena Ilmiah, Vol. 1., No. 1.

Hasan, Hamid. (2012). Pendidikan Sejarah Indonesia. Bandung: Risqi Press

Husmiati, Ratu. (2010). Kelebihan dan Kelemahan Media Film Sebagai Media Pembelajaran Sejarah. Jurnal Sejarah Lontar, Vol. 07 No. 2, Juli - Desember 2010.

Naim, Ahcmad. (2016). Aplikasi Cooperatif Learning Tipe Group Investigation (GI) pada Mata Pelajaran Sejarah Kebudayaan Islam di Kelas V Favorit MI Salafiyah Syafi'iyah Sukorejo Situbondo Tahun Pembelajaran 2015/2016. Al Murabbi, Vol. 3, No. 1.

Musfiqon. (2012). Pengembangan Media dan Sumber Pembelajaran. Jakarta: Prestasi Pustaka Raya. 
Purwono, J., Yutmini, S., dan Anitah, S. (2014). Penggunaan Meia Audio Visual pada Mata Pelajara Ilmu Pengetahuan Alam di Sekolah Menengah Pertama Negeri 1 Pacitan. Jurnal Teknologi Pendidikan dan Pembelajaran, Vol.2, No.2, April 2014.

Sofi, Euis. (2016). Pembelajaran Berbasis E-Learning pada Mata Pelajaran Sejarah Kebudayaan Islam Kelas VIII Madrasag Tsanawiyah Negeri. Tanzhim Jurnal Penelitian Manajemen Pendidikan, Vol. 1 tahun 1.

Sugiyono. (2008). Metode Penelitian Kuantitatif, Kualitatif, dan $R \& D$. Bandung: Penerbit Alfabeta.

Suryani, Nunuk dan Agung, Leo. (2012). Strategi Belajar Mengajar. Yogyakarta: Penerbit Ombak. 